\title{
Genetic Architecture of Yield and Some Morphophysiological Heat Tolerance Traits in Bread Wheat
}

\author{
Sunaina Rani*, Swati, Deepak Joshi, Prashant Goel and Ranjana \\ Department of Genetics and Plant Breeding, College of Agriculture, Govind Ballabh Pant \\ University of Agriculture and Technology, Pantnagar - 263 152, \\ Udham Singh Nagar, Uttarakhand, India \\ *Corresponding author
}

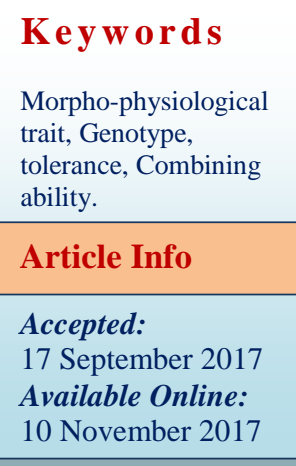

\section{Introduction}

Wheat (Tritium aestivum L.) is the most important crop and among the major three cereal crops that provides 20 percent of the total energy requirement in human food (Kempthorne et al., 1957). It contributes almost one-third to the total food grain in India, with more than half of their calories and nearly half of their protein (Kumar et al., 2015). The low level of productivity is mainly due to difficulty in availability of improved varieties, occurrence of diseases and changes in climatic conditions that pose severe threat to wheat production. Climatic changes have great implications on food production, food security and food safety. Changes in the temperature regimes are of particular importance to cultivation of cold loving crops like wheat and is particularly detrimental during reproductive development and grain filling stage.

Climate changes lead to temperature extremes, weather changes, erratic precipitation, changes in pest dynamics and overall changes in the micro-environment are expected to be more severe in the coming years. The major and foremost aspect in increasing production and productivity in 
wheat is adoption of high yielding, disease resistant, photo-thermo-tolerant and fertilizers responsive varieties and to minimize yield losses due to effect of high temperature on its growth and development (Reynolds and Borlaug, 2006). Climatic upheavals have become crucial to crop production. Hence, development of heat tolerant genotypes would deserve utmost priority to mitigate the production losses due to rise in temperature. In the process of developing high yielding varieties, breeders often face the problem of selecting desirable parents and crosses. In this context various breeding approaches have been suggested, the line $\times$ tester analysis method introduced by Kempthorne (1957) is one of the powerful tools available to estimate the combining ability effects and aids in selecting desirable parents and crosses for further use in breeding programmes (Rashid et al., 2007; Jain et al., 2012).

Development of heat tolerant wheat variety is now one of the priorities of agricultural research, Therefore the present investigation was carried out to study the combining ability of varieties/lines for yield and it's contributing traits and heat tolerance parameters in a line $\times$ tester mating design in bread wheat, With the objective of identify the best combining parent and their crosses on the basis of their general and specific combining ability for heat tolerant and grain yield parameters, under normal and late sown environments.

\section{Materials and Methods}

The present investigations were carried out at Norman E. Borlaug Crop Research Centre of Govind Ballabh Pant University of Agriculture and Technology, Pantnagar from rabi 2013-14 to rabi 2014-15. Pantnagar falls in Tarai region of Uttarakhand having subtropical and humid climate. It is situated in the foot hills of Himalayas (Shivalik range) at an altitude of $243.84 \mathrm{~m}$ above mean sea level at $29.5^{\circ} \mathrm{N}$ latitude and $79.3^{\circ} \mathrm{E}$ longitude Geographically. Fourteen diverse genotypes namely Raj 4229, DBW 110, HD 3122, HD 3123, PBW 644, PBW 675, WH 1126, BAV 92, KFA/2*KACHU, VL 944, FILIN/IRENA/5/CNDO/R143//ENTE/MEXI2/3/..., PBW65*/PASTOR, C 306, HD 2888 were selected as lines and three genotypes namely Raj 3765, DPW 621-50, UP 2572 were selected as testers on the basis of their origin, adaptability, yield potential and heat tolerance characters. Crosses were attempted during rabi, 2013-14 to generate F1s by using Line $\mathrm{X}$ tester mating design.

Final experimental trial comprising 17 parents along with their $42 \mathrm{~F} 1 \mathrm{~s}$ and 2 released wheat varieties PBW 590 and HD 2967 as checks were evaluated during rabi, 2014-15 in randomized block design with three replications in timely and late sown condition. Each plot consisted of 2 rows of $1 \mathrm{~m}$ length with a row to row and plant to plant distance of $23 \mathrm{~cm}$ and $10 \mathrm{~cm}$, respectively.

Data were recorded on plot basis for days to $75 \%$ heading, days to maturity, plant height $(\mathrm{cm})$, peduncle length, flag leaf area $\left(\mathrm{cm}^{2}\right)$, spike length $(\mathrm{cm})$, awn length $(\mathrm{cm})$, productive tillers per pant $(\mathrm{g})$, spikelets per spike, grain filling duration, grains per spike, grain weight per spike, 1000 grain weight, grain yield per plant $(\mathrm{g})$, biological yield per plant, harvest index (\%) (Donald 1962), heat susceptibility index, canopy temperature depression (CTD), chlorophyll content and relative injury \%. All the genotypes were planted in two separate experimental plots, i.e. timely sown $\left(\mathrm{E}_{1}\right)$ and late sown $\left(\mathrm{E}_{2}\right)$.

The flag leaf area was calculated using the following formula as suggested by Singh (1970):

Leaf area $=$ Leaf length $\times$ Width $\times 0.7238$ 
The heat susceptibility index (s) for yield characters per genotype was calculated using the following formula as described by Fischer and Maurer (1978):

$\mathrm{HSI}=(1-\mathrm{Xh} / \mathrm{X}) /(1-\mathrm{Yh} / \mathrm{Y})$

where $\mathrm{Xh}$ and $\mathrm{X}$ are the phenotypic means for each genotype under heat stressed and control conditions, respectively, and $\mathrm{Yh}$ and $\mathrm{Y}$ are the phenotypic means for all genotypes under heat stressed and control conditions, respectively.

A hand held infrared thermometer, (model AG-42, Tele temp crop, Fullerton CA) was used for instantaneous measurement of canopy minus air temperature as canopy temperature depression (Amani et al., 1996) at anthesis and 15 days after anthesis at an angle of $30^{\circ}, 50 \mathrm{~cm}$ above the canopy from horizontal and at one meter distance from the edge of the plot end. Data were recorded between 12:00 hrs.to 14:00 hrs.

Relative injury (\%) was calculated as per the formula given by Blum and Ebercon (1981):

$\mathrm{RI}(\%)=\{1-[1-(\mathrm{T} 1 / \mathrm{T} 2) / 1-(\mathrm{C} 1 / \mathrm{C} 2)]\} \times 100$

Where, $\mathrm{T}$ and $\mathrm{C}$ refer to treatment and control, respectively, and 1 and 2 refer to initial and final conductance readings, respectively.

Data recorded were subjected to analysis of variance according to Fisher (1918) to determine the significant differences among genotypes. Combining ability effects are very effective genetic parameters in deciding the next phase of breeding programs.

Combining ability analysis in line $\mathrm{x}$ tester scheme was carried out following the method given by Kempthorne (1957) and modified by Arunachalam (1974).

\section{Results and Discussion}

\section{Genetic variability}

Combining ability studies are useful in selection of parents and classifying them in terms of hybrid performance and to determine the nature and magnitude of gene effects involved in the expression of quantitative traits. Analysis of variance revealed significant differences among the progenies, parents, parents vs. crosses, crosses for all the traits under study in both E1 and E2, which validated further statistical analysis of data. On pooling the data of two environments, environment and environment $\mathrm{x}$ treatment significant values of squares for yield and yield components such as spike length, tillers per plant, 1000 grain weight, biological yield per plant, harvest index, days to heading, flag leaf area, grain per spike, spikelets / spike, grain weight / spike, grain yield/ plant as well as important thermo tolerant traits like Chlorophyll content, CTD value, relative injury were obtained which validates the further statistical analysis of data. This indicated the presence of diversity in the studied material. Analysis of variance for combining ability further reflected that variations due to line $\mathrm{x}$ tester interaction were significant for all the traits. This provides evidence of the presence of sufficient genetic variability among lines, testers, and hybrids and allows further assessment of general combining ability analysis. This finding is in conformity to the earlier report of Kant and Gupta (2002) who observed that mean squares due to female $\mathrm{x}$ male interaction were significant for all the characters under study except for days to heading, biological yield and grain yield.

\section{Analysis of variance for combining ability}

The analysis of variance for combining ability was performed for twenty traits including 
yield components and some physiological traits related to heat stress tolerance for E1, E2 environments and for pooled data. The mean squares due to crosses were partitioned into mean squares due to testers, due to lines and line $\mathrm{X}$ tester interaction components. The mean squares due to lines were significant for all the twenty characters in E1 and E2.

Mean squares due to testers were significant for fifteen characters namely days to heading, spike length, peduncle length, spikelets/ spike, 1000 grain weight, biological yield/ plant, harvest index, grain yield per plant, no. of grains/ spike, grain weight/ plant, flag leaf area, Chlorophyll content at anthesis and 15 days after anthesis, CTD value at anthesis and 15 days after anthesis, relative injury (\%) and heat susceptibility index in E1, while in E2 conditions seventeen characters viz. days to heading, plant height, peduncle length, awn length, productive tillers plant, spikelets/ spike, 1000 grain weight, biological yield/ plant, harvest index, grain yield per plant, no. of grains/ spike, grain weight/ plant, flag leaf area, Chlorophyll content at anthesis and 15 days after anthesis, CTD value at anthesis and 15 days after anthesis, relative injury (\%) and heat susceptibility index.

Mean squares due to line $\mathrm{X}$ tester interaction were found to be significant for thirteen characters namely plant height, peduncle length, awn length, tillers per plant, spikelets/ spike, 1000 grain weight, biological yield/ plant, harvest index, no. of grains/ spike, grain weight per spike, grain yield per plant, CTD at anthesis and 15 days after anthesis, relative injury (\%) and heat susceptibility index in E1 and seventeen characters in E2 namely days to heading, plant height, spike length, peduncle length, awn length, tillers per plant, spikelets/ spike, 1000 grain weight, harvest index, no. of grains/ spike, grain weight per spike, grain yield per plant, chlorophyll content at anthesis and 15 days after anthesis,
CTD at anthesis and 15 days after anthesis, relative injury (\%), flag leaf area and heat susceptibility index.

Analysis of variance showed that the mean squares of the treatments for all of 20 characters were significant. This revealed that significant differences were present in the genotypes for the characters studied in both E1 and E2. On pooling the data of two environments, environment and environment $\mathrm{X}$ treatment significant values of squares for yield and yield components such as days to $75 \%$ heading, days to maturity, plant height $(\mathrm{cm})$, peduncle length, flag leaf area $\left(\mathrm{cm}^{2}\right)$, spike length $(\mathrm{cm})$, awn length $(\mathrm{cm})$, productive tillers per pant $(\mathrm{g})$, spikelets per spike, grain filling duration, grains per spike, grain weight per spike, 1000 grain weight, grain yield per plant $(\mathrm{g})$, biological yield per plant, harvest index (\%), heat susceptibility index, canopy temperature depression (CTD) at anthesis, relative injury (\%), chlorophyll content at anthesis and 15 days after anthesis and environment $\mathrm{x}$ treatment significant values of squares for yield and yield components are days to $75 \%$ heading, plant height $(\mathrm{cm})$, peduncle length, flag leaf area $\left(\mathrm{cm}^{2}\right)$, spike length $(\mathrm{cm})$, awn length $(\mathrm{cm})$, productive tillers per pant $(\mathrm{g})$, spikelets per spike, grains per spike, grain weight per spike, 1000 grain weight, grain yield per plant (g), biological yield per plant, harvest index (\%), heat susceptibility index, canopy temperature depression (CTD) at anthesis, relative injury (\%), chlorophyll content at anthesis and 15 days after anthesis. This validates further statistical analysis of data.

Significant differences were observed among genotypes for all the twenty characters, indicating the presence of genetic variation for all the traits studied. Male and female interaction is far more important than male or female alone in deciding hybrid performance as revealed the results of the experiment. 
Table.1 Correspondence of per se performance and gca effects of best parents for different characters in F1 generation

\begin{tabular}{|c|c|c|c|}
\hline \multirow{2}{*}{ Character } & \multicolumn{3}{|c|}{ Best parent (gca effect) } \\
\hline & E1 & E2 & Pooled \\
\hline \multirow{2}{*}{ Plant height $(\mathrm{cm})$} & PBW 65*/ & DBW 110 & DBW 110 \\
\hline & PASTOR & & \\
\hline Spike length $(\mathrm{cm})$ & PBW 644 & VL944 & VL944 \\
\hline Peduncle length $(\mathrm{cm})$ & DBW 110 & HD 3122 & DBW 110 \\
\hline Awn length $(\mathrm{cm})$ & HD 3123 & VL 944 & HD 2888 \\
\hline Tillers/ Plant & Raj 4229 & HD 2888 & Raj 4229, HD 2888 \\
\hline Spikelets/ Spike & VL 944 & VL 944 & VL 944 \\
\hline 1000 Grain weight & HD 2888 & HD 3122 & HD 3122 \\
\hline Grain weight/ Spike & HD 3122 & PBW 644 & HD 3122 \\
\hline Grain yield/ Plant & HD 2888 & WH 1126 & PBW 644 \\
\hline Biological yield/ Plant & BAV 92 & DBW 110 & BAV 92 \\
\hline Harvest Index & HD 2888 & WH 1126 & WH 1126 \\
\hline $\begin{array}{l}\text { Chlorophyll content at } \\
\text { anthesis }\end{array}$ & BAV 92 & HD 2888 & PBW 644 \\
\hline $\begin{array}{l}\text { Chlorophyll content at } \\
\text { 15DAA }\end{array}$ & BAV 92 & PBW 644 & PBW 644 \\
\hline CTD at anthesis & WH 1126 & HD 2888 & HD 2888 \\
\hline CTD at 15 DAA & PBW 675 & VL 944 & PBW 675 \\
\hline Relative injury (\%) & BAV 92 & FILIN/IRENA... & BAV 92 \\
\hline Days to maturity & HD 3122 & HD 3122 & HD 3122 \\
\hline $75 \%$ Days to heading & Raj4229 & PBW 644 & Raj 4229 \\
\hline Grain filling duration & PBW 675 & HD 2888 & PBW 675 \\
\hline Flag leaf area $\left(\mathrm{cm}^{2}\right)$ & WH 1126 & WH 1126 & WH 1126 \\
\hline Grains/ Spike & VL 944 & VL 944 & VL 944 \\
\hline Heat susceptibility & & WH 112 & \\
\hline index & & & \\
\hline
\end{tabular}


Table.2 Correspondence of per se performance and sca effects of best crosses in F1 generation in different environments

\begin{tabular}{|c|c|c|c|}
\hline \multirow{2}{*}{ Character } & \multicolumn{3}{|c|}{ Best parent (sca effect) } \\
\hline & E1 & E2 & Pooled \\
\hline Plant height $(\mathrm{cm})$ & $\begin{array}{c}\text { PBW65*/PASTOR } \\
\text { x UP 2572 } \\
(-9.78)\end{array}$ & $\begin{array}{c}\text { Raj } 4229 \text { x DPW621- } \\
50(-10.51)\end{array}$ & $\begin{array}{c}\text { Raj } 4229 \times \text { DPW621-50 } \\
(-5.92)\end{array}$ \\
\hline Spike length $(\mathrm{cm})$ & $\begin{array}{c}\text { PBW65*/PASTOR } \\
\text { x DPW 621-50 } \\
(1.59)\end{array}$ & $\begin{array}{c}\text { PBW } 675 \times \text { Raj } 3765 \\
(1.12)\end{array}$ & HD 3122 x UP $2572(0.80)$ \\
\hline Peduncle length $(\mathrm{cm})$ & $\begin{array}{c}\mathrm{KFA} / 2 * \mathrm{KACHU} \mathrm{x} \\
\mathrm{DPW} 621-50 \\
(-4.55)\end{array}$ & $\begin{array}{l}\text { FILIN/IRENA... x } \\
\text { Raj } 3765 \text { (-16.73) }\end{array}$ & $\begin{array}{c}\text { FILIN/IRENA... x Raj } 3765(- \\
8.92)\end{array}$ \\
\hline Awn length $(\mathrm{cm})$ & $\begin{array}{l}\mathrm{KFA} / 2 * \mathrm{KACHU} \mathrm{x} \\
\mathrm{DPW} 621-50(1.17)\end{array}$ & $\begin{array}{c}\text { PBW } 675 \times \text { XP } 2572 \\
(1.80)\end{array}$ & PBW 675 x UP $2572(0.89)$ \\
\hline Tillers/ Plant & $\begin{array}{l}\text { PBW } 675 \times \text { xaj } \\
3765(6.95)\end{array}$ & $\begin{array}{l}\text { HD } 2888 \times \text { Raj } 3765 \\
(4.40)\end{array}$ & HD 2888 x Raj 3765 (3.96) \\
\hline Spikelets/ Spike & $\begin{array}{l}\text { PBW } 675 \times \text { DPW } \\
621-50(1.56)\end{array}$ & $\begin{array}{l}\text { BAV } 92 \text { x UP } 2572 \\
(2.14)\end{array}$ & BAV 92 x UP 2572 (1.46) \\
\hline 1000 Grain weight & $\begin{array}{c}\text { PBW } 65 * / \text { PASTOR } \\
\text { x DPW 621-50 } \\
(9.59)\end{array}$ & $\begin{array}{c}\text { WH } 1126 \text { x UP } 2572 \\
(4.79)\end{array}$ & WH 1126 x Raj 3765 (5.70) \\
\hline Grain weight/ Spike & $\begin{array}{l}\text { HD } 2888 \times \text { DPW } \\
621-50(0.78)\end{array}$ & $\begin{array}{l}\text { HD } 3123 \times \text { Raj } 3765 \\
(0.47)\end{array}$ & HD 3122 x UP $2572(0.45)$ \\
\hline Grain yield/ Plant & $\begin{array}{l}\text { HD } 2888 \times \text { DPW } \\
621-50(12.82)\end{array}$ & $\begin{array}{c}\text { PBW } 675 \text { x UP } 2572 \\
(2.79)\end{array}$ & HD 2888 x DPW $621-50(5.61)$ \\
\hline $\begin{array}{l}\text { Biological yield/ } \\
\text { Plant }\end{array}$ & $\begin{array}{l}\text { FILIN/IRENA... x } \\
\text { UP } 2572 \text { (51.77) }\end{array}$ & $\begin{array}{l}\text { BAV } 92 \times \text { UP } 2572 \\
(13.76)\end{array}$ & $\begin{array}{l}\text { FILIN/IRENA... x UP } 2572 \\
(26.05)\end{array}$ \\
\hline Harvest Index & $\begin{array}{l}\text { PBW } 644 \times \text { DPW } \\
621-50(4.51)\end{array}$ & $\begin{array}{c}\text { BAV } 92 \times \text { Raj } 3765 \\
(4.91)\end{array}$ & PBW 644 x UP 2572 (3.91) \\
\hline $\begin{array}{l}\text { Chlorophyll content } \\
\text { at anthesis }\end{array}$ & $\begin{array}{l}\text { HD } 2888 \times \text { DPW } \\
621-50(6.76)\end{array}$ & $\begin{array}{c}\text { WH } 1126 \times \text { Raj } 3765 \\
\text { (7.87) }\end{array}$ & HD 2888 x DPW $621-50$ (7.29) \\
\hline $\begin{array}{l}\text { Chlorophyll content } \\
\text { at 15DAA }\end{array}$ & $\begin{array}{c}\text { PBW65*/PASTOR } \\
\text { x DPW 621-50 } \\
(6.70)\end{array}$ & $\begin{array}{c}\text { PBW } 675 \times \text { Raj } 3765 \\
\text { (7.37) }\end{array}$ & FILIN/IRENA... x UP 2572 (5.70) \\
\hline CTD at anthesis & $\begin{array}{c}\text { PBW65*/PASTOR } \\
\text { x DPW 621-50 } \\
(1.67)\end{array}$ & $\begin{array}{l}\mathrm{KFA} / 2 * \mathrm{KACHU} \mathrm{x} \\
\mathrm{UP} 2572(2.05)\end{array}$ & $\begin{array}{c}\text { PBW65*/PASTOR x DPW 621-50 } \\
(1.78)\end{array}$ \\
\hline CTD at $15 \mathrm{DAA}$ & $\begin{array}{c}\text { Raj } 4229 \text { x Raj } 3765 \\
(1.46)\end{array}$ & $\begin{array}{l}\mathrm{KFA} / 2 * \mathrm{KACHU} \mathrm{x} \\
\text { Raj } 3765(2.22)\end{array}$ & DBW 110 x DPW 621-50 (1.33) \\
\hline Relative injury (\%) & $\begin{array}{c}\text { WH } 1126 \times \text { UP } 2572 \\
(-25.86)\end{array}$ & $\begin{array}{l}\text { BAV } 92 \times \text { DPW 621- } \\
50(-36.83)\end{array}$ & $\begin{array}{c}\mathrm{KFA} / 2 * \mathrm{KACHU} \times \mathrm{DPW} 621-50(- \\
16.80)\end{array}$ \\
\hline Days to maturity & - & - & HD 3123 x DPW $621-50(-2.00)$ \\
\hline $75 \%$ Days to heading & $\begin{array}{c}\text { C } 306 \times \text { Raj } 3765(- \\
1.67)\end{array}$ & - & C 306 x Raj 3765 (-1.54) \\
\hline Grain filling duration & $\begin{array}{c}\text { HD } 3123 \text { x UP } 2572 \\
(2.28)\end{array}$ & $\begin{array}{l}\text { HD } 2888 \times \text { DPW } \\
621-50(4.33)\end{array}$ & HD 2888 x DPW $621-50$ (3.29) \\
\hline Flag leaf area $\left(\mathrm{cm}^{2}\right)$ & $\begin{array}{l}\text { PBW } 675 \times \text { Raj } \\
3765(12.14)\end{array}$ & $\begin{array}{l}\text { VL } 944 \times \text { X UP } 2572 \\
(13.27)\end{array}$ & VL 944 x UP 2572 (7.09) \\
\hline Grains/ Spike & $\begin{array}{c}\text { PBW65*/PASTOR } \\
\text { x Raj } 3765(8.12)\end{array}$ & $\begin{array}{l}\text { BAV } 92 \times \text { UP } 2572 \\
(6.48)\end{array}$ & BAV 92 x UP 2572 (4.42) \\
\hline $\begin{array}{l}\text { Heat susceptibility } \\
\text { index }\end{array}$ & & & WH 1126 x UP $2572(-0.52)$ \\
\hline
\end{tabular}




\section{Estimates of combining ability effects}

The sca effects represent the non- additive gene action which is non- fixable. Normally the non-additive gene effects would not contribute tangibly in the improvement of grain yield in self-pollinated crops, except where the commercial exploitation of heterosis is feasible. In self-pollinated crops, however, the additive $\mathrm{x}$ additive type of interaction is also feasible in later generations and can be exploited for the improvement of grain yield and related traits. If crosses showing high SCA effects involve parents which are also good general combiner, these crosses could be exploited by simple methods like pedigree selection, provided the additive $\mathrm{x}$ additive component of interaction was significant.

BAV 92 was identified as best general combiner for maximum number of traits viz., biological yield/ plant, relative injury, chlorophyll content at anthesis and 15 days after anthesis and HD 2888 for 1000 grain weight, grain yield/ plant, harvest index followed by PBW 65*/PASTOR for plant height, relative injury (\%), HD 3122 for grain weight/ spike, days to maturity, Raj 4229 for tillers/ plant, 75\% days to heading, VL 944 for spikelets/ spike, grain/ spike, WH 1126 for CTD at anthesis, flag leaf area, PBW 675 for CTD at 15 days after anthesis, grain filling duration in timely sown condition (E1). In late sown condition (E2), VL 944 was recognized as good general combiner for maximum number of traits viz., spike length, awn length, spikelets/ spike, CTD at 15 days after anthesis and grain/ spike followed by HD 2888 for tillers/ plant, chlorophyll content at anthesis, CTD at anthesis and grain filling duration. PBW 644 was identified as best general combiner for maximum number of traits in pooled condition viz., grain yield per plant, chlorophyll content at anthesis and 15 days after anthesis, VL 944 for spike length, spikelets/ spike, grains/ spike, HD 2888 for awn length, tillers/ plant, CTD at anthesis, HD 3122 for 1000 grain weight, grain weight/ spike, days to maturity and WH 1126 for harvest index, flag leaf area, heat susceptibility index (Table 1).

PBW 65*/PASTOR x DPW 621-50 emerged as good specific combination for spike length, 1000 grain weight, chlorophyll content at 15 days after anthesis, CTD at anthesis followed by HD 2888 x DPW 621-50 for grain weight/ spike, grain yield/ plant, chlorophyll content at anthesis in timely sown condition (E1). BAV 92 x UP 2572 was good specific combination for spikelets/ spike, biological yield/ plant, grains/ spike followed by PBW $675 \times$ Raj 3765 for spike length, chlorophyll content at 15 days after anthesis and PBW 675 x UP 2572 for awn length, grain yield/ plant were good specific combinations in late sown condition (E2). In pooled analysis, HD2888 x DPW 621-50 for grain yield/ plant, chlorophyll content at anthesis, grain filling duration followed by HD 3122 x UP 2572 for spike length, grain weight/ spike, BAV $92 \mathrm{x}$ UP 2572 for spikelets/ spike, grains/ spike, FILIN/IRENA... x UP 2572 for biological yield/ plant, chlorophyll content at 15 days after anthesis were good specific combinations towards particular traits (Table 2).

Among these cross combinations some cross performed best with both parents involved in the cross having good general combining ability effects. This is highly desirable for effective selection. Singh and Chaudhary (1977) also reported good specific combinations in bread wheat with good gca effects of both the parents. Further, some cross combinations with one parent having good gca exhibited superior specific combining ability effect. This is in conformity with the results obtained by Kant et al., (2001). According to Kenga et al., (2004), 
cross-combinations with high means, favorable SCA estimates and involving at least one of the parents with high GCA would likely enhance the concentration of favorable alleles to improve target traits. These results were in close confirmation with the observation of Singh et al., (2013), Akbar et al., (2009) and Hammad et al., (2013) for $75 \%$ days to heading, Chandra et al., (2010), Singh et al., (2013) and Pawar et al., (2014) for days to maturity, Dagustu (2008), Chandra et al., (2010) and Singh et al., (2013) for palnt height, Dagustu (2008), Chandra et al., (2010), Singh et al., (2013) and Dholariya et al., (2014) for spike length, Saxena and Rawat (2011) and Padhar et al., (2013) for peduncle length, Chandra et al., (2010), Srivastava et al., (2012), Padhar et al., (2013) and Singh et al., (2013) for productive tillers per plant, Sayed et al., (2005), Heidari et al., (2006), Darwish et al., (2006), Dagustu (2008), Cifcil and Yagdil (2010), Saxena and Rawat (2011) and Zeeshan et al., (2013) for spikelets per spike, Akram et al., (2011), Khodadadi et al., (2012) and Singh et al., (2013) for 1000 grain weight, Padhar et al., (2013) and Singh et al., (2013) for biological yield per plant, Padhar et al., (2013), Desle and Mehta (2013) Devi et al., (2013) and Singh et al., (2013) for harvest index per plant, Padhar et al., (2013), Lohithaswa (2013) and Singh et al., (2013) for grains per spike, Dagustu (2008) and Singh et al., (2013) for grain weight per spike, Mahpara et al., (2008), Padhar et al., (2013) and Singh et al., (2013) for flag leaf area, Dhyani et al., (2013) and Cao et al., (2015) for chlorophyll content, by Punia et al., (2011), Mason et al., (2014) and Mondal et al., (2015) for CTD, Cossani et al., (2012) and Irshad et al., (2014) for relative injury, Vanpariya et al., (2006) and Tahmasebi et al., (2007), Chandra et al., (2010), Desle and Mehta (2013), Singh et al., (2013), Majeed et al., (2011), Rashid et al., (2012) and Pawar et al., (2014) for grain yield per plant, Punia et al., (2011), Abd-allah et al., (2013) and Agrawal et al., (2014) for heat susceptibility index.

Even after several years of research on developing heat tolerant varieties in cereals, there is no direct selection criteria for heat tolerant plants. On the basis of above traits paper may be concluded that different genotypes showed heat tolerance for different traits. However, the prime and ultimate objective of breeding program is high yield. Therefore on the basis of grain yield, out of 17 parental genotype BAV 92 in timely sown condition, VL 944 in late sown condition and PBW 644 in pooled condition and among 42 crosses, PBW65*/PASTOR x DPW 621-50 was the best specific cross in timely sown condition, BAV $92 \times$ UP 2572 in late sown condition and HD $2888 \times$ DPW 621-50 in pooled condition for most of the traits studied for heat tolerant. Therefore these genotypes may be used in breeding programes to develop heat tolerant high yielding varieties.

\section{Acknowledgement}

Authors acknowledge with thanks the Director, Experiment Station, GBPUAT, Pantnagar for providing necessary facilities to carry out the present investigation.

\section{References}

Abd-Allah, M.H., Soheir, M.H. and Amin, I.A. 2013.Genotypic Differences for Heat Tolerance Traits in Bread Wheat Using Five Parameters Genetic Model. Alex. J. Agric. Res., 58: 83-96.

Agrawal, A.P., Pandey, D. and Pandey, D. 2014. Variation parameters for heat tolerance index of wheat. J. Wheat Res., 6(1): 37-40.

Akbar, M., Anwar J., Hussain, M., Qureshi, M.H. and Khan, S. 2009. Line x tester analysis in bread wheat (Triticum aestivum L.). J. Agri. Res., 47(1): 21-30. 
Akram, Z., Ajmal, S.U., Khan, K.S., Qureshi, R. and Zubair, M. 2011. Combining Ability estimates of some yield and quality related traits in spring wheat (Triticum aestivum L.). Pak. J. of Botany, 43(1): 221-231.

Arunachalam, V. 1974. The falacy behind the use of modified line $\mathrm{x}$ tester design. Indian J. Genet., 34: 280-287.

Blum, A. and Ebercon, A. 1981.Cell membrane stability as a measure of drought and heat tolerance in wheat. Crop Sci. J, 21: 43-47.

Cao, X., Mondal, S., Cheng, D., Wang, C., Liu, A., Song, J., Liu, J. 2015. Evaluation of agronomic and physiological traits associated with high temperature stress tolerance in the winter wheat cultivars. Acta Physiologiae Plantarum, 37(4): 90.

Chandra, D., R. Sharma, S. Rani, D.K. Singh, R. Sharma and S.K. Sharma. 2010. Genetic variability for quantitative traits in wheat [Triticum aestivum L. Em. Thell].Plant Archives, 10(2): 871-874.

Çifcil, E.A. and Yağdı1, K. 2010. The Research of the Combining Ability of Agronomic Traits of Bread Wheat in F1 and F2 Generations. J. of Agri. Faculty of Uludag University, 24(2): 85-92.

Cossani, C.M. and Reynolds, M.P. 2012. Physiological traits for improving heat tolerance in wheat. Plant Physiology, 160: 1710-1718.

Dagustu, N. 2008.Combining ability analysis in relation to heterosis for grain yield per spike and agronomic traits in bread wheat (Triticum aestivumL.). Turkish J. of Field Crops, 13(2): 49-61.

Darwish, I.H.I., Sayed, E. and Awady, W.A.E. 2006.Genetic studies of heading date and some agronomic characters in wheat. Annals of Agril. Sci. Moshtohor, 44(2): 461-486.

Desale, C.S. and Mehta, D.R. 2013. Heterosis and combining ability analysis for grain yield and quality traits in bread wheat (Triticum aestivum L.). Elect. J. of Plant Breeding, 4(3): 1205-1213.

Devi, E.L., Swati, Goel, P., Singh, M., Jaiswal, J.P. 2013. Heterosis studies for yield and yield contributing traits in bread wheat (Triticum aestivum). The Bioscan, 8(3): 908-909.

Dholariya, N.D., Akabari, V.R., Patel, J.V. and Chovatia, V.P. 2014. Combining ability and gene action study for grain yield and its attributing traits in bread wheat.Elect. J. of Plant Breeding, 5(3): 402-407.

Dhyani, K., Ansari, M.W., Rao, Y.R., Verma, R.S., Shukla, A. and Tuteja, N. 2013. Comparative physiological response of wheat genotypes under terminal heat stress. Plant Signaling and Behavior, 8(6): 245-264.

Fischer, R.A. and Maurer, R. 1978. Drought resistance in spring wheat cultivars: 1 . Grain yield responses. Aust. J. Agric. Res., 29: 897-912.

Fisher, R. A. 1918. The correlation among relatives on the supposition of Mendelian inheritance. Trans Royal Society of Edinburgh, 52: 399-433.

Hammad, G., Kashif, M., Munawar M., Ijaz, U., Raza, M.M., Saleem, M. and Abdullah.2013. Genetic Analysis of Quantitative Yield Related Traits in Spring Wheat (Triticum aestivum L.). American-Eurasian J. Agric. and Environ. Sci., 13(9): 1239-1245.

Heidari, B., Rezai, A. and Maibody, S.A.M. 2006.Diallel analysis for the estimation of genetic parameters for grain yield and grain yield components in bread wheat. J. Sci. Technol. Agril. Res., 10(2): 121-140.

Irshad, M., Ghaffar, A., Khaliq, I., Aslam, M., Hussain, N. and Iqbal, J. 2014. Genetic Control of Thermo-Tolerance in Spring Wheat as Measured by Canopy Temperature Depression and Cell 
Membrane Thermostability. Int. J. of Sci. and Res., 3(10): 1877-1884.

Jain S.K., and E. V. D. Sastry, "Heterosis and combining ability for grain yield and its contributing traits in bread wheat (Triticum aestivum L.)," RRJAAS, vol. 1, pp. 17-22, 2012.

Kant L and Gupta H S. 2002 Potential yield enhancement by combining winter and spring wheat gene pools. SABRAO J of Breeding and Genet 34(2): 95-106.

Kant L, Mani V P and Gupta H S. (2001). Winter $\mathrm{x}$ spring wheat hybridization. A promising avenue for yield enhancement. Plant Breeding 120(3): $255-258$

Kempthorne, Q. 1957. An introduction to genetic statistics. John Willy \& Sons.Inc. New York. pp. 468-471.

Kenga, R., S. O. Alabi, and S. C. Gupta, "Combining ability studies in tropical sorghum (Sorghum bicolor (L.) Moench)," Field Crops Research, vol. 88, no. 2-3, pp. 251-260, 2004.

Khodadadi, E., Aharizad, S., Sabzi, M., Shahbazi, H. and Khodadadi, E. 2012. Combining ability analysis of bread quality in wheat, Annals of Biological Res., 3(5): 2464-2468.

Kumar, A., Prasad, B. and Kumar, A. (2015). Study of variance components of combining ability for yield, its attributing traits in common bread wheat. Elixir Agriculture; 81: 3142531426.

Lohithaswa, H.C., Desai, S.A., Hanchinal, R.R., Patil, B.N., Math, K.K., Kalappanavar, I.K., Bandivadder, T.T. and Chandra Shekhar C.P. 2013. Combining ability in tetraploid wheat for yield, yield attributing traits, quality and rust resistance over environments. Karnataka J. Agric. Sci., 26(2): 190-193.

Mahpara, S., Z. Ali and M. Ahsan, 2008. Combining ability analysis for yield and yield related traits among wheat varieties and their F1 hybrids..Int. J. Agric. Biol., 10: 599-604.

Majeed, S., Sajjad, M. and Khan, S.H. 2011.Exploitation of non-additive gene actions of yield traits for hybrid breeding in spring wheat. J. Agri. and Social Sci., 7(4): 131-135.

Mason, R.E. and Singh, R.P. 2014. Considerations When Deploying Canopy Temperature to Select High Yielding Wheat Breeding Lines under Drought and Heat Stress. Agronomy, 4(2): 191-201.

Mondal, S., Mason, R.E., Huggins, T. and Hays, D.B. 2015. QTL on wheat (Triticum aestivum L.) chromosomes 1B, 3D and 5A are associated with constitutive production of leaf cuticular wax and may contribute to lower leaf temperatures under heat stress. Euphytica, 201(1): 123-130.

Padhar, P.R., Chovatia, V.P., Jivani, L.L. and Dobriya, K.L. 2013.Combining ability analysis over environments in diallel crosses in bread wheat (Triticum aestivum L.). Int. J. of Agri. Sci., 9(1): 49-53.

Pawar, K.K., Yadav, K.S., Bhaghel, S.K., Singh, A.K. 2014. Study of diallel analysis in bread wheat for grain yield and its component. Int. J. Sci. Res., 3: 63-67.

Punia, S., Shah, M., Ranwha, B.R.M., and Paratap, M. 2011. Genetic analysis for high temperature tolerance in bread wheat. Crop A. Society, 19(3): 149-163.

Rashid, M., A. A. Cheema, and M. Ashraf, "Line $\mathrm{x}$ tester analysis in basmati rice," Pakistan Journal of Botany, vol. 39, no. 6, pp. 2035-2042, 2007.

Rashid, M., Khan, A. and Iftikhar, R. 2012. Genetic Studies for Yield and Yield Related Parameters in Bread Wheat. American-Eurasian J. of Agri. and Env. Sci., 12(12): 1579-1583. 
Reynolds, M.P. and Borlaug N.E. 2006. International collaborative wheat improvement: impacts and future prospects. J. Agric. Sci., 144: 3-17.

Saxena, P. and Rawat, R.S. 2011. Combining ability and heterosis for yield and quality traits in bread wheat (Triticum aestivum L.em.Thell). Pantnagar J. of Res., 9(2): 170-177.

Sayed, E.E.A.M. and Moshref, M.K. 2005.Breeding for yield, yield components and some agronomic characters in bread wheat. Egyptian $J$. Agric. Res., 83(2): 665-679.

Singh K., Singh U.B. and Sharma S.N. 2013.Combining ability analysis for yield and its components in bread Wheat (Triticum aestivum L. em. Thell.). J. Wheat Res. 5(1): 63-67.

Singh V P and Choudhary R K. (1977) Line X Tester analysis for combining ability in triticale. Crop Improvement 4: 74-80.

Singh, R.J. 1970. Hybrid vigour in pearl millet (Pennisetum typhoides) (Burm. F.) (Staph \& Hubb). Indian J. Agric. Sci., 49: 974-976.

Srivastava, M.K., Singh, D. and Sharma, S. 2012. Combining ability and gene action for seed yield and its components in bread wheat [Triticum aestivum L. em.Thell]. Elect. J. Plant Breed., 3(1): 606-611.

Tahmasebi, S., Khodambashi, M. and Rezai, A. 2007. Estimation of genetic parameters for grain yield and related traits in wheat using diallel analysis under optimum and moisture stress conditions. J. Sci. Tech. Agril. Nat. Reso., 11(1): 229-241.

Tariq M, Ali Q, Khan A, Khan GA, Rashid B, Rahi MS, Ali, A, Nasir IA, Husnain T. (2014). Yield potential study of Capsicum annuum L. under the application of PGPR. Adv. life sci., 1(4): 202-207.

Vanpariya, L.G., Chovatia, V.P. and Mehta, D.R. 2006.Combining ability studies in bread wheat (Triticum aestivum L.). National Journal of Plant Improvement, 8(2): 132-137.

Zeeshan, M., Arshad, W., Ali, S., Tariq, M., Hussain, M. and Siddique, M. 2013. Estimation of Combining Ability effects for some yield related metric traits in intra-specific crosses among different spring wheat (Triticum aestivum L.) genotypes. Int. J. of Advanced Res., 1(3): 6-10.

\section{How to cite this article:}

Sunaina Rani, Swati, Deepak Joshi, Prashant Goel and Ranjana. 2017. Genetic Architecture of Yield and Some Morphophysiological Heat Tolerance Traits in Bread Wheat. Int.J.Curr.Microbiol.App.Sci. 6(11): 2155-2165. doi: https://doi.org/10.20546/ijcmas.2017.611.254 